\title{
RBSI and MFP Alumni Academic and Professional Updates
}

Alumni of the APSA Ralph Bunche Summer Institute (RBSI) and the APSA Minority Fellows Program (MFP) report the following updates and achievements:

Rachel Gillum (RBSI Class of 2007 and MFP, 2008-2009) received her PhD in 2014 from Stanford University and is currently a post-doctoral fellow at the Stanford Center on International Conflict and Negotiation. Her research areas are Muslim-American integration, race and ethnic politics, terrorism, and counterterrorism policy.

Mai Hassan (RBSI Class of 2007) received her PhD from Harvard University in 2014 and is currently a President's Post-Doctoral Research Fellow at the University of Michigan. Hassan's research areas include comparative politics, with a focus on authoritarian regimes and a regional focus on sub-Saharan Africa.

Chryl Laird (RBSI Class of 2004) received her PhD in 2014 from Ohio State University and is currently an assistant professor of political science and African American studies at Saint Louis University.

Tehama Lopez-Bunyasi (RBSI Class of 200o) has joined the faculty of George Mason University at the School for Conflict Analysis and Resolution. She is the author of "Breathing Difference, Sharing Empowerment." Chicana/o Latina/o Law Review 32:2 (2014): $67-80$ and has coauthored "Brown Ballots in the Buckeye State" in The Sleeping Giant is Awake: The Pivotal Role of the Latino Electorate in the 2012 Election (Gabriel R. Sanchez,

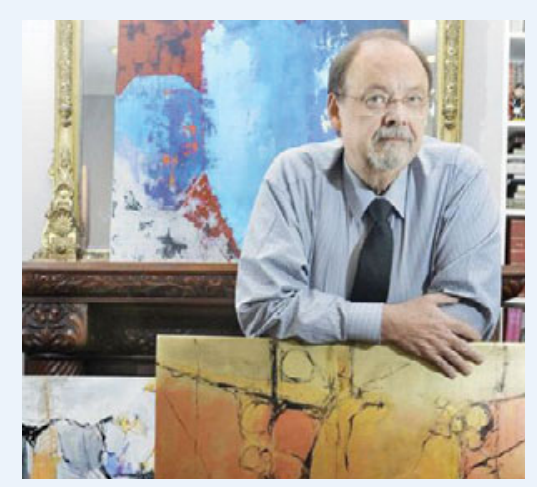

Rob Hauck pictured with some of his original artwork. ed.) (forthcoming with Michigan State University Press). Lopez-Bunyasi's research is grounded in conflicts around race and ethnicity in the United States with specializations in racial attitudes and ideologies, structural inequality, whiteness, Latino racial identity, and political behavior.

Lavar T. Thomas (RBSI Class of 2012) is currently serving in the Peace Corps as a community health volunteer and as an elected representative on the Project Advisory Committee in Rwanda. He graduated from Clark University in May 2013. Prior to joining the Peace Corps, Thomas was a legislative aide in the office of state representative Jeffrey Sanchez in Boston, Massachusetts.

Christopher Towler (RBSI Class of 2007) is assistant professor of African American Politics at Western Washington University. Towler received his $\mathrm{PhD}$ from the University of Washington in 2014. His research areas include American politics, race, and ethnicity and methodology with an emphasis in political behavior, ideological predispositions, alienation, political allegiance, and support.

Laurie Tumaneng (RBSI Class of 2012; MFP, 2013-2014), a second year PhD student in the department of political science at the Pennsylvania State University, has received the three year National Science Foundation Graduate Research Fellowship (NSFGRF) to work on a project with her advisor, Gretchen Casper. The project will address how the Compacts of Free Association with the United States affects democratization in

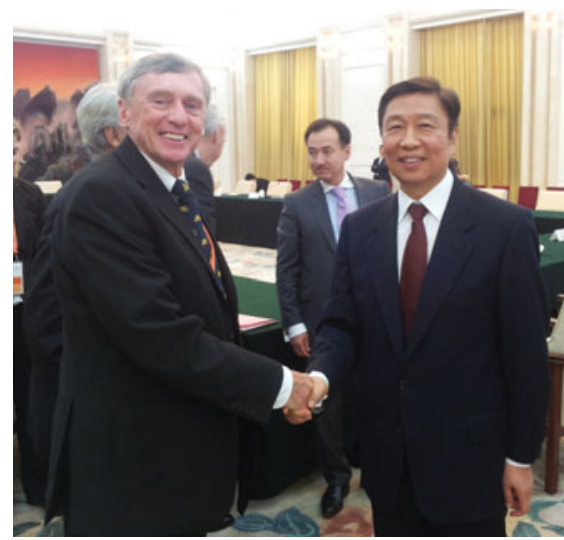

Past APSA President John Aldrich (2013-2014) shakes hands with Chinese Vice President Li Yuanchao in the Great Hall of the People. Aldrich visited China in September, 2014.

the Micronesian islands over time.

Sherri Wallace (RBSI Class of 1988 and MFP, 1989-1990), associate professor at the University of Louisville, has co-authored a chapter "Being Black Academic Mothers" in a volume, What the Village Gave Me:Conceptualizations of Womanhood, edited by D. Davis-Maye, A. Dale Yarber, and T. E. Perry and published by University Press of America, Inc./ Rowman \& Littlefield. Wallace is a member of the Committee on Teaching and Learning and the APSA Teaching and Learning Conference program committee.

Chris Zepeda-Millán (RBSI Class of 2003) is an assistant professor in the Department of Ethnic Studies at University of California, Berkeley. Zepeda has a book manuscript under contract with Cambridge University Press entitled Immigrant Mass Mobilization: Threat, Identity, and Activism. Zepeda also received a \$30,00o grant from the Russell Sage Foundation Presidential

\section{FAREWELL!}

Robert Jean-Pierre Hauck, who served as editor of PS: Political Science and Politics for 25 years (1989-2014), has announced his retirement. During his editorship, Hauck guided the journal from a small publication to become the expanded, peer-reviewed journal and official association register that it is today. He received his $\mathrm{PhD}$ in political science from the University of Chicago, and he taught at Vanderbilt University's Institute for Public Policy Studies and was assistant director of the Center for Children and Families Policy. He also taught for Smith College and Holy Cross College. He joined the APSA staff in 1982 as program associate and grew into multiple subsequent roles including director of international programs, director of the Centennial Campaign and Center, and deputy director of the association. APSA and the discipline as a whole will ever appreciate his invaluable service. 
Authority Award for a survey on the political attitudes and incorporation of US-born children of documented and undocumented immigrants (Co-principle investigator with Alex Street), 2013.

\section{Fellowship Applica- tion Period Open}

The Council of European Studies invites eligible candidates to apply for its MellonCES Dissertation Completion Fellowships and the Pre-Dissertation Research Fellowships!

Mellon-CES Dissertation Completion Fellowships are targeted at late-stage humanities graduate students working on Europe, and include a $\$ 25$,00o stipend and fee waivers. All applications due January 26, 2015.

CES Pre-Dissertation Fellowships, which support early-stage graduate students in both the social sciences and humanities, provide funding for up to two months of travel and research in Europe to strengthen dissertation projects. Applications due January 19, 2015.

\section{Institutions Guide Published}

The Council of European Studies Guide to Institutions Focused on the Study of Europe, 2014 Edition, is now available on IngentaConnect. The Guide is part of the CES Resource Guide series and provides a comprehensive and practical guide to more than 400 European Studies institutions from around the globe.

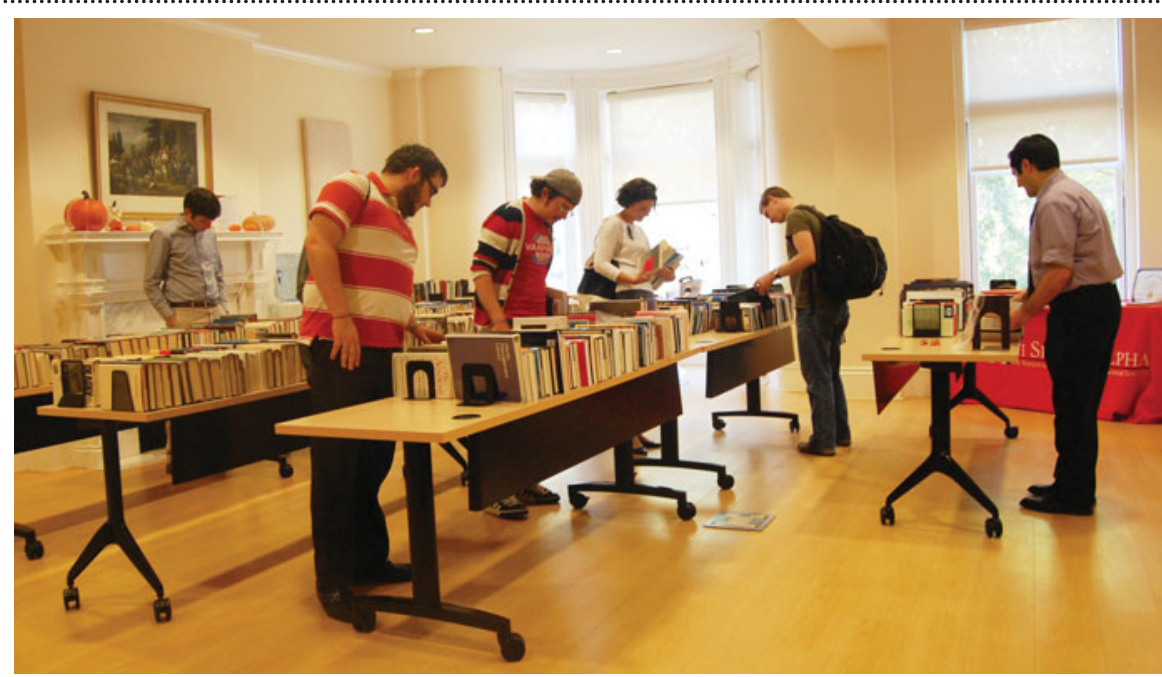

APSA headquarters staff hosted the second annual "Trick- or-Read" event in late October at the APSA offices in Washington, DC. APSA offered a variety of books, old and new, to young professionals and political science graduate and undergraduate students during the day-long open house. In addition to helping grow the professional libraries of these individuals, the event featured reduced student membership rates for on-site applications and festive "treats" throughout the day. The event offered great opportunities to network with APSA's internal political scientists, those in practice here in the metropolitan DC area, as well as other students at various stages. More than 80 people attended. The event was cosponsored by Pi Sigma Alpha. (Photo courtesy of Drew Meadows.)

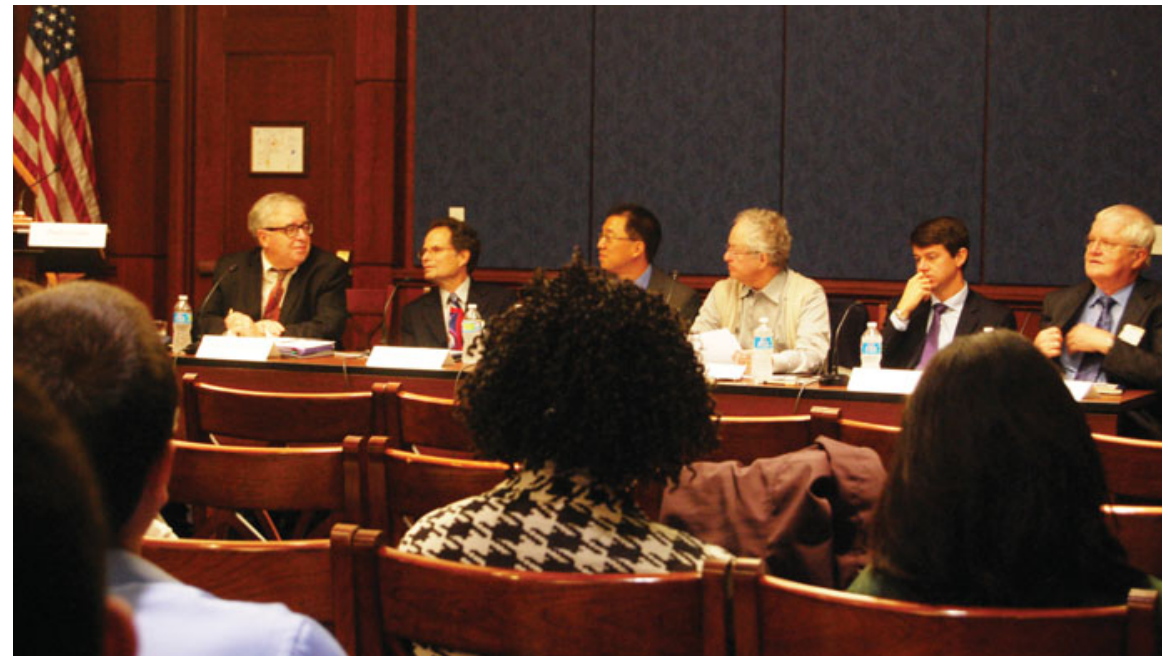

Political scientists (pictured left to right) James Campbell, chair, University at Buffalo, SUNY; Alan Abramowitz, Emory University; Charles Tien, Hunter College \& The Graduate Center, CUNY; Michael Lewis-Beck, University of lowa; John Sides, George Washington University; and Robert Erikson, Columbia University present their research on election forecasting in the Capitol Visitor's Center on October 22, 2014. Paul Gronke, Reed College, (not pictured) moderated the briefing. (Photo courtesy of Drew Meadows.)

\section{FAREWELL!}

After serving at APSA for 17 years as director of the Congressional Fellowship Program (1997-2014), Jeffrey Biggs has stepped into retirement. He received an MA in political science on a Fulbright from Victoria University, Wellington, New Zealand and his $\mathrm{PhD}$ in American studies from George Washington University. Biggs went on to serve 21 years in the Foreign Service and was an APSA Congressional Fellow in 1985 (Congressman Thomas Foley, D-WA, and Senator Alan Simpson, R-WY), later serving on Foley's senior staff from 1987 to 1994. He has authored Honor in the House: Speaker Tom Foley (co-authored with Foley), A Congress of Fellows: Fifty Years of the American Political Science Association Congressional Fellowship Program 1953-2003, and a number of journal articles. APSA, along with the many fellows Jeff advised, will forever appreciate his legacy of service.

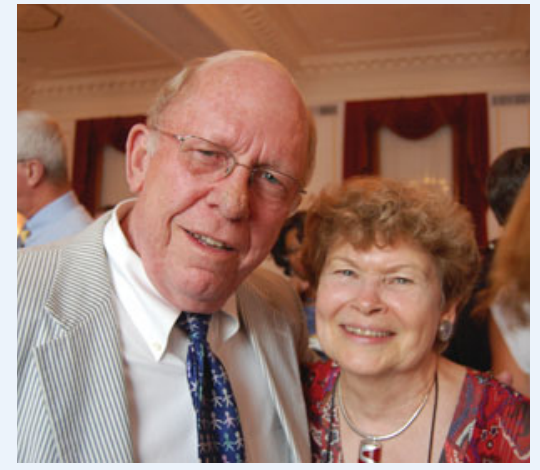

Jeff Biggs pictured with his wife at a reception in his honor at the APSA 2014 Annual Meeting. 